\title{
Japan - U.S. Relations under the Abe Doctrine: Shifting Policy in East Asia Regional Stability
}

\author{
Hendra Manurung \\ Jababeka Education Park, Jl. Ki Hajar Dewantara \\ Kota Jababeka, Cikarang Baru, Bekasi \\ President University Campus, Indonesia \\ h_manurung2002@president.ac.id \\ DOI: https://doi.org/10.32890/jis2017.13.5
}

\begin{abstract}
Reelection of Shinzo Abe as Prime Minister provides a favorable climate for both Donald Trump's first presidential visit to Japan and an improvement of Chinese-Japanese-U.S. bilateral relations. In the 22 October 2017 ballot, Abe's dominant Liberal Democratic Party (LDP) and its coalition partner Komeito, secured a two-thirds majority in the House of Representatives, the lower house of Japan's bicameral legislature. The coalition already holds a supermajority, required for amending the constitution, in the upper house. It justified Abe for calling the national elections a year earlier than needed to secure a public mandate for addressing the growing North Korean threat and to validate popular support for deepening national economic reforms, which have had recent success in boosting Japan's growth rate and the stock market. Still the outcome gave Abe a mandate for his policies. However, his stewardship was unclear as several other factors contributed to LDP's overwhelming victory. At the structural level, Japan's first past the post-electoral system tends to amplify electoral wins in comparison to proportional representation systems. Abe's foreign and security policies highly charged with ideological revisionism contain the potential to shift Japan onto a new international trajectory in East Asia. Its degree of articulation and energy makes for a doctrine capable of displacing the Yoshida Doctrine that has been Japan's dominant grand strategy in the post-war period. Abe will remain pragmatic and not challenge the status quo. However, Abe has already begun to introduce radical policies that appear to transform national security, US-Japan alliance ties and relations with China and East Asia. The Abe Doctrine is dynamic but high risk. Abe's revisionism contains fundamental contradictions that may ultimately limit national effectiveness.
\end{abstract}

Keywords: Abe Doctrine, Shinzo Abe, national leader, Japan, regional security.

\section{Introduction}

In December 2002, Prime Minister Shinzo Abe's stunning return to power in a landslide election victory, and the consolidation of his leadership in a repeat victory in December 
2014, heralded the resurgence, also for Japan, of a more assertive, high-profile and high-risk foreign and security policy. Abe's status was as an arch revisionist ideologue, combined with the track record of his first administration in 2006 to 2007. It indicated that he would inevitably harbor intentions to shift Japan towards a more radical external agenda characterized by a defense posture less fettered by past anti-militaristic constraints, a more fully integrated US-Japan alliance and an emphasis on value-oriented diplomacy with East Asian states and beyond.

It emphasized how Abe's diplomatic agenda (Abe Gaikō) that has been so distinctive and forcefully articulated in the past years might be labeled as a doctrine capable of rivaling, and even of displacing the doctrine of Prime Minister Yoshida Shigeru that has famously determined Japan's entire post-war international trajectory. In contrast to Abe's more muscular international agenda, the so-called Yoshida Doctrine from Yoshida Rosen, forged in the aftermath of the total defeat in the Pacific War, has long emphasized the need for a pragmatic and low-profile foreign policy, a highly constrained defense posture, reliance but not over-dependence on the US-Japan security treaty and the expedient rebuilding of economic and diplomatic ties with East Asian neighbors ${ }^{1}$.

In mid-March 2013, the ongoing dispute between China and Japan over the Senkaku Islands in the East China Sea or known in China as the Diaoyu Islands triggered a national controversial debate about the trajectory of Japanese politics, and the return to power of the old guard; Liberal Democratic Party (LDP), further enlivened it. Moreover, as LDP's comeback leader, Prime Minister Shinzo Abe is such a self-assertive figure that the argument has become inflamed. The Japanese and the international media have already concluded the matter, coalescing around the idea that Japan is presently undergoing a policy shift to the right. But the truth is not so simple, and this consensus conclusion is neither accurate nor useful ${ }^{2}$. The objective of this paper was to engage and to assess the significance of the 'Abe Doctrine' for Japan's international trajectory and whether it would lend new dynamism or actually reinforce the dead-end diplomacy of recent Japanese administrations.

The impact of the 'Abe Doctrine' can best be comprehended through its underpinning revisionist ideology. Abe's ideology derives from a tradition of pre-war colonial and wartime attempts to assert for Japan a position as a first-rank nation and leader within Asia and a post-war ambition to be regarded as an autonomous state, US equal partner and liberal-capitalist power facing down authoritarianism. Abe's pursuit of this role demands the casting off of international and domestic constraints imposed by defeat and the negative burden of history. In order to end the post-war regime and return Japan to great power status, the Doctrine must overturn taboos on constitutional revision, patriotic education, the historical legacies of the 'comfort women' or 'Jugun Ianfu', the Tokyo Tribunals and prime ministerial visits to the Yasukuni Shrine. 


\section{The Abe Doctrine: From Post-War Regime to Great Power}

The Abe Doctrine has always contained the potential to set Japan on a new international trajectory ${ }^{3}$. Nevertheless, after Abe's return to the premiership for a second stint, a feat for a Japanese politician, previously achieved only by Yoshida in the post-war period, he remained keen to stress the continuities with past policies. Japanese government policymakers have been at pains to deny that Abe was in any way a dangerous nationalist, and to stress that his design was simply to tackle the domestic and international constraints that have prevented Japan from overcoming its past torpor in foreign and security policy ${ }^{4}$. This view of Abe as essentially pragmatic and able to rein in his more radical instincts has been corroborated by a range of other commentators who predicted that in his second premiership he would prioritize the consolidation of his domestic political support, most especially because his first administration foundered owing to apparent inattention to the basic management of domestic politics, a hyperactive foreign policy and ultimate failure to deliver on security promises to the US for the prolongation of the Japan Self-Defense Force's (JSDF) refueling operations in the Indian Ocean in support of the international coalition in Afghanistan 5 .

Despite protestations that Abe is essentially pragmatic in outlook, it is clear that his worldview has always been underpinned by a strong revisionist ideology now fully surfacing as the principal driver of Japan's foreign and security policies. Abe and his supporters' perspective stands in contrast to the previously dominant paradigm of the Yoshida Doctrine which, apart from being broadly conservative in orientation, was largely bereft of ideological content and functioned on the basis of expedient adaptation of Japan's national interests to the prevailing status quo in the East Asian regional and US-led international systems. It is this strong ideological content and disposition to overturn the status quo which charges Abe's foreign policy with energy and makes it worthy of a true competitor doctrine to that of Yoshida.

The Yoshida Doctrine was focused on Japan's cautious navigation through the post-war international system as a defeated and low-profile power. The Abe Doctrine is fixated on the recognition of Japan's position as a first-rank advanced industrial democracy, and hence the rightful restoration of its place amongst the great powers, even if this necessitates attempts to adjust rather than adapt to the extant international system. Abe's vision for Japan is derived from a tradition of revisionism prevalent amongst much of his Seiwa Seisaku Kenkyūkai faction (Fukuda Takeo - Abe Shintarō - Mori Yoshirō faction; currently Machimura Nobutaka faction) within the LDP, the ideological and organizational lineage which is ultimately traceable back to Prime Minister Kishi Nobusuke, his grandfather and founder of the progenitor faction ${ }^{6}$.

Kishi Nobosuke, a former bureaucrat involved in the industrial development of Japanesecontrolled Manchukuo, and later Minister of Munitions during the war and thus involved in the Japanese colonial project for the integration of the region under the Greater East 
Asia Co-Prosperity Sphere, was originally arrested under the post-war Allied Occupation as a 'Class A' war crime suspect'. Later, Kishi avoided trial by the International Military Tribunal for the Far East and was able to reenter politics after the end of the Occupation. He found his faction and eventually attained the premiership from 1957 to 1960 . Kishi's faction and brand of conservative politics attracted to his banner a number of right-wing nationalist and anti-communist politicians.

Kishi strove above all to begin to restore Japan's national autonomy as a great power and portrayed himself as a Cold War warrior in support of the US security strategy in the region and globally. He sought autonomy in a fashion- somewhat reminiscent of the Pan-Asianism ideology of the Greater East Asia Co-Prosperity Sphere. It was to resuscitate a vision of Japan as a leader of a new Asianism or 'Ajia no Meishu', and in particular the leader of a more integrated Southeast Asia, in order to demonstrate to the US that Japan was not an isolated state and was capable of international initiatives and deserved of more equal status $^{8}$. Most notably, Kishi made his first overseas trips as Japan Prime minister to the Asian countries and the first by any Japanese prime minister to the region in the post-war era, rather than take up the ritual homage like other Japanese premiers to the U.S. Kishi engaged in vigorous diplomacy in Southeast Asia; in 1957 he visited Burma, Thailand, South Vietnam, Cambodia, Laos, Malaysia, Singapore, Indonesia and Philippines, and put forward a proposal for the creation of a Southeast Asian Development Fund under Japan's

direction. Also in the same year, Kishi visited Taiwan as a demonstration of his anticommunist credentials. He also visited India, Pakistan, Ceylon, Australia and New Zealand.

\section{Japan Policy in Asia}

Kishi Nobosuke's other most famous endeavor was the revision of the US and Japan Security Treaty in 1960 to strengthen the Cold War bilateral cooperation and most crucially to attempt a more equal standing for Japan as a security partner. The Japanese domestic political unrest surrounding Kishi's strong-arm tactics in pushing the revision through the National Diet triggered his eventual resignation.

The Kishi faction was, for much of the remainder of the Cold War period, marginalized from power by the LDP's other more domestically powerful factions: the Kōchikai (Ikeda Hayato - Ōhira Masayoshi Miyazawa Kiichi faction-currently Kishida Fumio faction) and Heisei Kenkyūkai/Tsushima (Satō Eisaku - Tanaka Kakuei-Takeshita Noboru faction currently Nukuga Fukushirō faction). The LDP mainstream helped to fully consolidate the so-called 1955 system or 'Gojūnen Taisei' of uninterrupted LDP one-party dominance and a pragmatic focus largely on domestic economic growth and maintenance of the Yoshida Doctrine in line with the foreign policy.

However, as the LDP mainstream factions' economic policies and political support faltered after the end of the Cold War period with the collapse of the Japanese economic bubble, 
the anti-mainstream was able to regain power in the guise of Prime Minister Mori's faction. Apart from a brief period the LDP was out of power, displaced by the Democratic Party of Japan (DPJ) between 2009 and 2012, the Mori faction has proceeded to produce four of the five last LDP prime ministers, including the most famously Koizumi Junichiro between 2001 and 2006 and Abe for his two terms in office. The consequence of the breakdown of Japan's post-war 1955 system, increasing political instability and the return of the descendants of the Kishi faction from the right of the political spectrum to capture power was the creation of opportunities for Koizumi, but most particularly Shinzo Abe, to implement their long-held ideological program for the transformation of the Japanese domestic and foreign policies.

Koizumi, although an initiator of significant changes in foreign and security policies and applauded by many for his willingness to overcome past restraints to enable actions such as the dispatch of the Japan Special Defense Force to support US-led coalitions in Afghanistan and Iraq, was arguably less ideologically oriented and more opportunistic in foreign policy, seeking to use these issues to build international legitimacy to effect his true ideological agenda of neoliberal reform for the Japanese economy and political system. In contrast, Abe is arguably less ideological in economic policy, only experimenting with 'Abenomics' as an opportunity to create the second time round the domestic political support necessary to provide a free hand to pursue his true ideological agenda in foreign policy ${ }^{9}$.

Since 2012, Abe's ideological stance and objectives in many ways echo those of his grandfather in seeking recognition of Japan's standing amongst the first rank, or 'Tier One', of capitalist powers, recovery of its autonomy as an international player, recognition as a crucial US partner and leader in Asian countries, and confrontation of hostile authoritarian regimes in the contemporary period in the guise of China and North Korea ${ }^{10}$.

Shinzo Abe argues that this project for the restoration of Japan as a great power can be achieved only by overturning the constraints of the past imposed on Japanese freedom of international action. Abe and the Japan Revisionists posit that defeat in the Pacific War, the meting out of the victor's justice of the Tokyo tribunals and the conviction of 'Class A' war criminals without alleged precedent in International Law, the unwarranted singling out of Japan as an aggressor in East Asia compared to other imperial great powers, and the externally imposed reforms for the demilitarization of the Japanese Occupation (19391945) have created a burden of history that has robbed Japan of its true national identity and vitality.

Hence, for Shinzo Abe and his supporters it is only by unburdening itself from this socalled masochistic or 'Jigyaku-Teki' history and by escaping from the post-war or 'Sengo Dakkyaku' regime can be viewed essentially as a regime of defeat that Japan can start to rehabilitate its national strength and autonomy ${ }^{11}$. Abe has talked of Japan restoring its sense of national patriotism, along with a new stress upon the promotion of the values of democracy, liberal market economy and the rule of law. It is all values drawn in implicit yet deliberate contradistinction to the authoritarianism of China and North Korea ${ }^{12}$. 
Shinzo Abe, who returned to power in late 2012 following the Liberal Democratic Party's landslide victory in the Diet's lower-house elections, has pushed aggressively to realize his ambitious agenda. Within a year of being elected, Abe instituted sweeping reforms to the national security apparatus. In December 2013, Japan announced the formation of a National Security Council (NSC) modeled after that of the United States. The council streamlines the Prime Minister's decision-making process while breaking down the various bureaucratic barriers that have impeded effective crisis management. Tokyo also enacted a controversial state-secrets law that tightened the government's control of sensitive and classified information, enabling the NSC to centralize the handling of intelligence.

The ASEAN Summit in Manila, Philippines, on 14 November 2017 resulted in 4 (four) commitments made by ASEAN leaders and its counterpart on the South China Sea dispute, terrorism, humanitarian crisis in the Rakhine State of Myanmar, and the Korean Peninsula Crisis $^{13}$.

Thus, if Abe was expected to take any radical action in international policy, the general consensus was that it would wait until securing a working majority in the Upper House elections in July 2013 to match the straight majority secured by the Liberal Democratic Party (LDP) in the Lower House in the December 2012 elections ${ }^{14}$. At the tactical level, Abe skillfully exploited the recent resurgence in his popularity and the division among the LDP's opponents. The main opposition Democratic Party, disintegrated into rival conservative and leftist wings; neither did well on 22 October 2017.

Moreover, even then the presumption was that Abe would be wary of pushing his strongest revisionist agenda for fear of disaffecting the LDP's dovish New Komeito coalition partner, of worsening the already fraught relations with China and South Korea and even of alienating a US not keen to see Japan unsettling the strategic landscape as it was in the midst of a 'rebalance' towards the East Asia region. Japan's major focus under Abe was instead thought to be domestic economic recovery, and if there was to be any radicalism and international risks posed, these were to be in the form of his eponymous policy of 'Abenomics' and its associated 3 (three) arrows of massive quantitative easing, fiscal stimulus and economic restructuring. These predictions surrounding Abe's agenda were largely borne out for the first six months of his administration. Despite Abe's stated intent at the start of his administration to review the Japanese government's statement on the 'comfort women' (Jugun Ianfu) issue which was an ambition held over from his first premiership that his government subsequently backed away in early 2014 , conscious of the negative reaction domestically and internationally.

Moreover, even though Abe's Cabinet was replete with noted right-wing conservatives, three of whom had visited the controversial Yasukuni Shrine on 15 August 2013 to commemorate the anniversary of Japan's defeat in the Pacific War, the prime minister himself stayed away. Instead, he seemed content to stress his revisionist credentials with photo opportunities sitting in a Ground Self-Defense Force (GSDF) main battle tank and 
Air Self-Defense Force (ASDF) trainer jet ${ }^{15}$. Furthermore, even though Abe maintained a tough stance towards China in the ongoing tensions in the East China Sea over the Senkaku/ Diaoyu territorial dispute and issues of maritime security, he began to initiate vigorous diplomacy with the US and other East Asian states to project Japan's international presence in contradistinction to China. His administration did not pursue the hard-line security options intimated in the LDP's election manifesto. Abe himself repeatedly called for dialogues with China and stressed Japan's attachment to a form of revamped 'proactive contribution to peace' (Sekkyoku-Teki Heiwashugi).

Abe's apparent restrained statesmanship won plaudits domestically and internationally: efforts to revitalize the Japanese economy earned him the depiction of a Superman-like figure on the cover of The Economist in May 2013 ${ }^{16}$. Abenomics garnered praise at the Group of Eight (G8) summit in the UK in June. It appeared overall that Abe's slogan 'Japan is back' was highly credible ${ }^{17}$. However, from autumn 2013 onwards, the full guise of Abe's revisionist agenda, and thus the propensity for setting Japan on a new radical trajectory in foreign and security policy, has become readily apparent.

Abe's initiation of new developments in Japan's defense doctrines and capabilities and the US-Japan relations provided the first signs of a revisionist agenda coalescing in line with the expectations of many commentators ${ }^{18}$. Nevertheless, Abe's decision to pay an official visit to the Yasukuni Shrine on 26 December 2013, exactly within one year of his assuming office, indicated not only that his revisionism was gathering momentum but also that there were now diminishing constraints on the full extent of the prime minister's ambitions. The visit surprised and drew sharp criticism from policy-makers and the public not only in China and South Korea but also in the US, and even the wider international community, as a highly provocative move with potentially deep ramifications for Japan's international reputation and regional stability.

Now that Abe's 'true colors' (Abe-iro) and revisionist agenda are finally revealed, and he appears secure in power until possibly 2018, questions have begun to fly about the significance of Japanese foreign and security policies. Japanese government policy-makers have remained engaged in increasingly problematic attempts to deny Abe's nationalist or even militarist bent and to stress continuities with past policies, whilst at the same time arguing that the prime minister's challenging of taboos is essential for Japan to overcome its malaise in responding to external pressures from China and North Korea and expectations from the US and the international community for a wider commitment to global security.

Meanwhile, those critical of Abe have ramped up their arguments that he is intent on an irresponsible campaign of overturning post-war constraints on Japanese military power that will only worsen security relations with China and alienate South Korea and other East Asian partners. The objective of this paper was to engage and assess the significance of the 'Abe Doctrine' for Japan's international trajectory and whether it will lend new dynamism or actually reinforce the dead-end diplomacy of recent Japanese administrations. The paper undertook this task by analyzing in depth the ideological foundations and policy objectives 
of the 'Abe Doctrine' and how it plays out across three pivotal dimensions, or another three policy arrows, of Japan's foreign and security policy: Japanese defense capabilities; the evolution of the US-Japan alliance; and relations with China, South Korea, the Association of Southeast Asian Nations (ASEAN) and other key states in the Asia-Pacific region.

Moreover, in appraising the impact of the 'Abe Doctrine' across these three dimensions, the writer argues that whilst neither apologist or critical views of Abe as a figure of post-war continuity nor a rewind to a pre-war ultranationalist past are entirely accurate, there can be no doubt that his administration is fundamentally revisionist and nationalist in outlook and is thus set upon, and in fact is already shifting Japan towards a radical trajectory. This can be seen in the rapid-fire changes to security policy in the form of the new National Security Strategy (NSS) and the National Security Council (NSC), State Secrecy Law, Three Principles of Defense Equipment Transfers and most significantly breach of the ban on the exercise of the right to collective self-defense.

In US-Japan relations, Abe has moved ahead with the first revision of the Defense Guidelines since 1997 with the aim of enabling Japan to support the US in not just the East Asia region but also in global contingencies; the plans for the massive relocation of US Marine Corps Air Station Futenma within Okinawa; and Japanese participation in the Trans-Pacific Partnership (TPP). They are all designed to boost the US Rebalance to the region. In East Asia, Abe's diplomacy has looked into buildings a coalition of like-minded states to assist in the quiet encirclement of China. In turn, this paper argued that even though the rise of the 'Abe Doctrine' is undoubtedly generating a more proactive Japanese foreign policy and has achieved some quick wins in raising international profile and influence. Over the mediumto long-term, the policy is strategically short-sighted, hard to sustain and ultimately counterproductive to Japan's national interests. Hence, this paper tended towards a verdict more in line with the critiques of the 'Abe Doctrine' that view it as steering Japan towards a new dead end in foreign and security policies, a dead end largely of Japan's own making which will result not only in an eventual lack of international momentum but also, along the way, serious long-term collateral damage to regional relations. It moves towards emphasizing the rise and then probable failure of the 'Abe Doctrine'. The signs are already apparent that the Abe administration is beginning to struggle in the substantive implementation of domestic and foreign policies that can be understood as largely inevitable because of a series of internal and hence inescapable contradictions.

These relate, perhaps ironically, to a doctrine that might pride itself on a clearly articulated ideology and strategy, and to ideological tenets that are fundamentally incompatible with the mechanisms and objectives that it seeks to utilize and achieve.

The eventual conclusion is that the 'Abe Doctrine' is likely to riven with its own contradictions that rather than producing a new and clear strategic paradigm for Japan, or reverting back to the previous traditions of the Yoshida Doctrine, it reinforces an increasingly prominent and 
long-term trend in Japanese foreign policy characterized at various turns by unpredictability, obduracy and antagonism towards regional neighbors and even the US, or what might be termed as a new 'Resentful Realism'.

\section{Conclusion}

As the first non-Western country to modernize its society, government, and economy, Japan has been one of the most powerful Asian states since the late nineteenth century up to the present time. Despite over two decades of economic stagnation, it remains highly developed, and its economy is slowly adjusting to a postindustrial era. The Shinzo Abe government is competent and organizationally complex, while elites in both the public and private sectors are highly educated and capable. Japan's natural resources are limited, but its other national resources are well-developed.

Indeed, though hampered by groupthink and risk aversion, Japan's political, corporate, and intellectual leaders achieve high levels of national performance, despite ongoing internal rivalry, group interests and the lack of individual leadership. These strengths translate into military capabilities that are unmatched by most states in the Asia-Pacific region. However, Japan's self-imposed restrictions on overseas military operations and an unwillingness to build a military force commensurate with its economic size have resulted in a smaller and less operationally experienced military than would otherwise be expected.

Japan's greatest need is to embrace radical structural reform in its economy, thereby revitalizing innovation and competitiveness and sparking sustainable postindustrial growth. Therefore, Japan should embrace Prime Minister Shinzo Abe's plans for a more regionally and internationally engaged foreign policy integrated with other Asian leaders' political economy interests that offer unstinting liberal support for an open, pursuing rules-based order in Asia-Pacific.

Japan must expand and modernize its military, even beyond Abe's current plans, and free itself from domestic restraints that prevent it from playing a central role with liberal allies in maintaining regional stability.

\section{References}

Abe, Shinzō, Utsukushii Kuni, E, Tokyo \& Bunshun Shinsho. (2006). Abe, Shinzō, 'Asia's Democratic Security Diamond', Project Syndicate. Retrieved from https://www. projectsyndicate.org/commentary/a-strategic-alliance-forjapan-and-india-by-shinzoabe

Abe, Shinzō. (2013). The bounty of the open seas: Five new principles for Japanese diplomacy, Jakarta. Retrieved from https://www.mofa.go.jp/announce/pm/abe/ abe_0118e.html 
Abe, Shinzō. (2013). Japan is back. CSIS, Washington D.C., Retrieved from https://www. mofa.go.jp/announce/ pm/abe/us_20130222en.html

Abe, Shinzō. (2013). Japan is back: A conversation with Shinzō Abe. Foreign Affairs. Retrieved from https://www. foreignaffairs.com/discussions/interviews/japan-isback

Abe, Shinzō. (2014). Japan and NATO as "natural partners": Speech by Prime Minister Abe. Retrieved from https:// japan.kantei.go.jp/96_abe/statement/201405/nato.html

Abe, Shinzō. (2014). Press conference by Prime Minister Abe. Retrieved from https://japan. kantei.go.jp/96_abe/ statement/201405/0515kaiken.html

Abe, Shinzō. (2014). The 13th IISS Asian Security Summit - The Shangri-La Dialogue - Keynote Address by Prime Minister Abe. Retrieved from https://japan.kantei. go.jp/96_abe/statement/201405/0530kichokoen.html

Abe, Shinzō \& Hyakuta Naoki. (2014). Nihon yo, Sekai no Mannaka de Sakihokore. Tokyo, Waku Kabushikikaisha.

Aida, Hiro. (2013). Does Shinzō Abe's election really herald a more militarist Japan? Discuss Japan: Japan foreign policy forum. Retrieved from https://www.japanpolicyforum.jp/ en/archives/politics/ pt20130305170000.html

Anzen Hoshō no Hō-teki Kiban no Saikōchiku ni Kansuru Kondankai, Anzen Hoshō no Hō-teki Kiban no Saikōchiku ni Kansuru Kondankai Hōkokusho. (2008). Retrieved from http://www.kantei.go.jp/jp/singi/anzenhosyou/houkokusho

Anzen Hoshō no Hō-teki Kiban no Saikōchiku ni Kansuru Kondankai, Anzen Hoshō no Hō-teki Kiban no Saikōchiku ni Kansuru Kondankai Hōkokusho. (2014) .Retrieved from http://www.kantei.go.jp/jp/singi/ anzenhosyou2/dai7/houkoku

Armitage, R., L., \& Nye, J. S. (2012). The US-Japan alliance: Anchoring stability in Asia. Washington D.C., CSIS. Retrieved from http://csis. org/files/publication/120810_ Armitage_USJapanAlliance_Web.

Asagumo Shimbunsha. (2001). Bōei Handobukku. Tokyo, Asagumo Shimbunsha

Asagumo Shimbunsha. (2001). Bōei Handobukku. Tokyo, Asagumo Shimbunsha.

Asia Policy Point. (2013). The "Facts" ad New Jersey Star, November 4, 2012, An introduction to Japan's conservative nationalists. Washington D.C., Asia Policy Point.

Asō, Tarō. (2007). Jiyū to Hanei no Ko.Tokyo, Gentōsha

Berger, T., U. (2012). War, guilt and world politics after World War II, Cambridge, Cambridge University Press.

Berger, T., U. (2014). Abe's perilous patriotism: Why Japan's new nationalism still creates problems for the region and the US-Japan alliance. A Japan Chair Special Edition Platform, CSIS. Retrieved from http://csis.org/files/publication/141003_Berger_ AbePerilousPatriotism_Web.

Bōeichōhen, Bōei Hakusho. (1995). Tokyo, Ōkurasho Insatsukyoku

Bōeishōhen,Bōei Hakusho. (2011). Tokyo, Zaimushō Insatsukyoku

Bōeishō, (2013). 'Chūki Bōeiryoku Seibi Keikaku (Heisei 26nendo-Heisei 30nendo) ni tsuite'.. Retrieved from http://www.mod.go.jp/j/approach/ agenda/guideline/2014/ pdf/chuki_seibi26-30 
Bōeishō. (2013). Heisei 26nen ikō ni kakawaru Bōei Keikaku no Taikō ni tsuite. Retrieved from 17 December. Retrieved from http://www.mod.go.jp/j/approach/agenda/ guideline/2014/pdf/20131217

Bōeishō. (2013). Waga kuni no bōei to yosan (an): Heisei 26nen yosan no gaiyō. Retrieved from 25 December 2013. http://www.mod.go.jp/j/yosan/yosan.html

Bōeishō. (2013). Waga kuni no bōei to yosan (an): Heisei 27nen yosan no gaiyō. Retrieved from 25 December. Retrieved from http://www.mod.go.jp/j/yosan/2015/yosan

Bōeishō. Waga (2014). kuni no bōei to yosan: Heisei 27nendo gaisan yōkyū no gaiyō. 29 August. Retrieved from http://www.mod.go.jp/j/yosan/2015/gaisan

Choong, W. (2014). The ties that divide: History, honour and territory in Sino-Japanese relations, London, Routledge.

Curtis, G. L. (2013). Japan's cautious hawks: Why Tokyo is unlikely to pursue an aggressive foreign policy. Foreign Affairs, 92(2), March/April, 78-86.

Doak, Kevin M. Shinzo. (2013). Abe's civic nationalism. Japan Chair Platform. 15 May 2013. Retrieved from http://csis.org/publication/japan-chair-platform-shinzoabescivic-nationalism

Embassy of the United States, (2013). Tokyo, Japan. Statement on Prime Minister Abe's December 26 visit to Yasukuni Shrine. Retrieved from http://japan.usembassy.gov/ e/p/tp-20131226-01.html

Ennis, Peter. (2013). For Abe, talks with Obama came down to "take what you can get". Dispatch Japan. 26 February 2013. Retrieved from http://www.dispatchjapan. com/ blog/2013/02/for-abe-talks-with-obama-came-down-to-takewhat-you-can-get.html.

Gaikō Fōramu. (2013). Tokushū Nihon gaikō no shinkijiku. Gaikō Fōramu, no. 225. April 2007, pp. 8-33. George Mulgan, Aurelia. Abe rocks Japan's constitutional boat. East Asia Forum, 21 May 2013. Retrieved from http://www.eastasiaforum. org/2013/05/21/abe-rocks-japans-constitutional-boat

Glosserman, B. (2014). Abe's dilemmas. PacNet, no. 37, 30 May. Retrieved from http:// csis.org/publication/pacnet-37-abes-dilemmas

Goldman, Justin. (2013). An amphibious capability in Japan's self-Defense force: Operationalizing dynamic defense. Naval War College Review, 66(4), Aautumn, 116-34.

Green, M. (2001). Japan's reluctant realism: Foreign policy challenges in an era of uncertain power.New York: Palgrave.

Green, M., \& Hornung, J., W. (2014). Ten myths about Japan's collective self-defense change: What the critics don't understand about Japan's constitutional reinterpretation. The Diplomat, 10 July. Retrieved from https://thediplomat.com/2014/07/ten-mythsabout-japanscollective-self-defense-change.

Hanssen, Ulv. (2014). 'Abe looks through legal loophole for collective self-defense. East Asia Forum. 30 May. Retrieved from http://www.eastasiaforum. org/2014/05/30/abelooks-through-legal-loophole-for-collective-selfdefense

Hara, Yoshihisa (1995). Kishi Nobusuke: Kensei no Seijika. Tokyo, Iwanami Shinsho.

Hayashi, Keiichi. (2014, January 5). China risks becoming Asia's Voldemort. The Daily Telegraph. Retrieved from https://www.telegraph.co.uk/news/ worldnews/asia/ japan/10552351/China-risks-becoming-AsiasVoldemort.html 
Hughes, C.,W. (2004). Japan's reemergence as a 'normal' military power, Oxford, Oxford University Press.

Hughes, C.,W. (2006). The political economy of Japanese sanctions towards North Korea: Domestic coalitions and international systemic pressures. Pacific Affairs, 79 (3), $455-$ 481.

Hughes, C.,W. (2012). Japan's remilitarisation, London, Routledge, 2009. Hughes, Christopher W. China's military modernization: US allies and partners in Northeast Asia. In Ashley J. Tellis and Travis Tanner (Eds.), China's Military Challenge: Strategic Asia 2012-13, Seattle, Washington D.C., National Bureau of Asian Research, pp. 197-239.

Hughes, C., W. (2012). The Democratic Party of Japan's new (but failing) grand security strategy: From "resentful realism" to "reluctant realism"'. Journal of Japanese Studies, . 38(1), 109-140.

Hughes, Christopher W. (2013). Japan's remilitarization and constitutional revision. In Peter N. Stearns (Ed.), Demilitarization in the contemporary world. Chicago, Illinois, University of Illinois Press, 127-156.

Hughes, Christopher W., and Krauss, Ellis, S. (2007). Japan's new security agenda. Survival, 49 (2), 157-176.

Ishiba, Shigeru. (2014). Nihonjin no tame no "Shūdan-teki Jieiken" Nyūmon. Tokyo, Shinchō. Japanese Ministry of Defense. (2013). Defense of Japan, 122.

Jiyū Minshutō, Jūten Seisaku (2012). Retrieved from https://jimin.ncss.nifty.com/pdf/ seisaku_ichiban24

Jiyū Minshutō, (2012). Nihonkoku Kenpō Kaisei Sōan, 27 April. Retrieved from https:// www. jimin.jp/policy/policy_topics/pdf/seisaku-109

Jiyū Minshutō. (2013). Nihonkoku Kenpō Kaisei Sōan Q \& A: Zōhoban, October. Retrieved from https://www.jimin.jp/policy/pamphlet/pdf/kenpou_qa

Katz, Richard. (2013). Voodoo Abenomics: Japan's failed comeback plan. Foreign Affairs, 93(3),133-141.

Kenpō Chōsa. (2004). Suishin Giin Renmei: Kiyaku, 'Kenpō Chōsa Suishin Giin Renmei: Kiyaku. 14 April. Retrieved from http://www.kenpoukaigi.gr.jp/ tyousakai/20040414kenpougiren-kiyaku\&meibo

Kobayashi, Yoshinori. (2010). Abe Shinzō: sengo rejīmu no ritokusha o itsu made mo hōchi shite wa ikenai. Kibō no Kuni Nihon: Kyūjin no Seijika to Shinken Shōbu, Tokyo, Asuka Shinsha, 272-314.

Kokka Anzen Hoshō Kaigi, Kokka Anzen Hoshō ni tsuite. (2013). Retrieved from http:// www.cas.go.jp/jp/siryou/131217anzenhoshou/nss-j

KOMPAS. (2017). ASEAN Raih jaminan China dalam isu Laut China Selatan (LCS). 15 November.

Konishi, Weston S. (2008). Will Japan be out of tune with a concert of democracies?, AsiaPacific Bulletin, East-West Center, no. 19, 27 June. Retrieved from http://www. eastwestcenter.org/sites/default/files/private/ apb019

Liu, Xiaoming. (2014). Britain and China won the war together. The Daily Telegraph, 1 January. Retrieved from http://www.telegraph.co.uk/ comment/10546442/LiuXiaoming-China-and-Britain-won-the-wartogether.html 
Maeda, Tetsuo and Iijima, Shigeaki, (2003). Kokkai Shingi kara Bōeiron o Yomidoku. Tokyo, Sanseido

Matsumoto, Kenichi.(2013). Is “Japan's move to right” true? Second Abe administration faces test of realism. Discuss Japan: Japan Foreign Policy Forum, 5 March 2013. Retrieved from http://www.japanpolicyforum.jp/ en/archives/politics/pt20130305180000.html

Matsuki, Kunitoshi. (2011). Jūgun Ianfu Renkō wa Nakatta: Seifu Chōsa Shiryō ga Akasu Kōno Danwa no Uso, Tokyo, Meiseisha,

MEXT. (2013). Kyōiku Kihon Hōan, Shinkyū Taisho Hyōmokuji. Retrieved from http:// www.mext. go.jp/b_menu/houan/an/06042712/005

Minister for Foreign Affairs Kishida, (2013). Minister for Defence Onodera, Secretary of State Kerry, Secretary of Defense Hagel. Joint statement of the security consultative committee: Toward a more robust alliance and greater shared responsibilities. 3 October. Retrieved from http:// www.mofa.go.jp/mofaj/files/000016028

Ministry of Defence Japan. (2010). National defence program guidelines for FY2011 and beyond. 17 December. Retrieved from http://www.mod. go.jp/e/d_act/d_policy/pdf/ guidelinesFY2011

Ministry of Foreign Affairs Japan. (1993). Statement by the chief cabinet secretary Yōhei Kōno on the result of the study of the issue of "comfort women". 4 August. Retrieved from http://www.mofa.go.jp/policy/ women/fund/state9308.html

Ministry of Foreign Affairs Japan. (1995). Statement by Prime Minister Tomiichi Murayama on the occasion of the 50th anniversary of the war's end. 15 August. Retrieved from http://www.mofa.go.jp/announce/press/ pm/murayama/9508.html

Ministry of Foreign Affairs Japan. (1997). The guidelines for Japan-US defence cooperation. Retrieved from http://www.mofa.go.jp/region/namerica/us/security/guideline2.html

Ministry of Foreign Affairs Japan. (2013). Joint statement by the United States and Japan. 22 February Retrieved from http://www.mofa.go.jp/region/namerica/us/pmv_1302/ pdfs/20130222_01

Ministry of Foreign Affairs Japan. (2013). Joint statement of the ASEAN-Japan Commemorative Summit: "Hand in hand facing regional and global challenges". 14 December. Retrieved from https://www.mofa.go.jp/ files/000022451

Ministry of Foreign Affairs Japan. (2013). Statement by Prime Minister Abe: Pledge for everlasting peace. 26 December. Retrieved from http://japan.kantei. go.jp/96_abe/ statement/201312/1202986_7801

Ministry of Foreign Affairs Japan. (2014). Joint press release on Japan-Australia summit meeting. 7 April. Retrieved from http://www.mofa.go.jp/ files/000034801

Ministry of Foreign Affairs Japan. (2014) Tokyo declaration for Japan-India special strategic and global partnership. 1 September. Retrieved from https:// www.mofa. go.jp/files/000050549

Ministry of Foreign Affairs. (2014). Japan. Interim report on the revision of the guidelines for Japan-US defense cooperation. 8 October 2014. Retrieved from http://www. mofa.go.jp/mofaj/files/000055169

Ministry of Foreign Affairs Japan.. (2014). Regarding discussions toward improving JapanChina relations. 7 November. Retrieved from http://www. mofa.go.jp/a_o/c_m1/cn/ page4e_000150 
Mochizuki, M. M., \& Porter, S., P. (2013). Japan under Abe: Toward moderation or nationalism?. The Washington Quarterly, 36 (4), 25-41.

Naikaku Kanbō Kokka Anzen Hoshō Kaigi Secchi Junbishitsu. (2013). Kokka Anzen Hoshō ni Tsuite, Setsumei Shiryō. Retrieved from https://www. kantei.go.jp/jp/singi/ka_ yusiki/dai6/siryou 1

Naikaku Kanbō. (2014). Kuni no zonritsu o mattōshi, kokumin o mamoru tame no kireme no nai anzen hoshō hōsei no seibi ni tsuite. 1 July. Retrieved from http://www.cas. go.jp/jp/gaiyou/jimu/pdf/anpohosei

Naikaku Kanbō. (2014). "Kuni no zonritsu o mattōshi, kokumin o mamoru tame no kireme no nai anzen hoshō hōsei no seibi ni tsuite". ichimon, ittō, 1 July. Retrieved from https://www.cas.go.jp/jp/gaiyou/jimu/housei_seibi. html

Narusawa, Muneo. (2013). be Shinzō, a far-right denier of history. The Asia-Pacific Journal, 11(1). Retrieved from https://japanfocus. org/-Narusawa-Muneo/3879

Nihon Kaigi (2013). Jigyō Sentā, Kore Dake wa Shitte Okitai Daitōa Sensō: 20 no Saishin Kiso Chishiki, Tokyo, Meiseisha,

Nihon (2008). no Zento to Rekishi Kyōiku o Kangaeru Giin no Kai, Nankin no Jissō: Kokusai Renmei wa "Nankin 2manin Gyakusatsu" Sura Mitomenakatta, Tokyo, Nisshin Hōdō,

Nishikawa, Shinichi. (2013). Naikaku Hōseikyoku: hō no banjin ka? Kenryoku no jijo ka? Tokyo, Satsuki Shobō,

Office of the White House Press Secretary, (2014). Joint press conference with President Obama and Prime Minister Abe of Japan. 24 April. Retrieved from http://www. whitehouse.gov/the-press-office/2014/04/24/joint-pressconference-president-obamaand-prime-minister-abe-japan

Oros, A., L.(2013). Does Abe's rightward shift threaten his legacy?', PacNet, no. 2. Retrieved from http://csis.org/publication/pacnet-2does-abes-rightward-shift-threaten-his-legacy

Oros, A., L. (2014, July 1). Japan's cabinet seeks changes to its peace constitution - Issues new "interpretation" of Article Nine'. Asia-Pacific Bulletin, no. 270. Retrieved from https://www.eastwestcenter.org/sites/default/files/ private/apb270_0

Park, C., H. (2013). The double life of Shinzō Abe. Global Asia, 8(2), Summer, 78-82.

Penn, M. (2014). Japan and the war on terror: Military force and political pressure in the US-Japanese alliance. London, I.B. Tauris.

Penny, M. (2013). The Abe cabinet: An ideological breakdown. Retrieved from http:// japanfocus.org/events/view/170

Pilling, D. (2014). Bending adversity: Japan and the art of survival, London, Penguin Books.

Pyle, Kenneth B. (2007). Abe Shinzō and Japan's change of course. NBR Analysis, Seattle, National Bureau of Asian Research, October 2006.

Pyle, Kenneth B. Japan rising: The resurgence of Japanese power and purpose, New York, Public Affairs.

Reinhart, Ian E. (2013). Collective self-defense and US-Japan security cooperation. EastWest Center Working Papers, Politics, Governance and Security Series, no. 24. Retrieved from http://www.eastwestcenter.org/sites/ default/files/private/pswp024. pp. 1-22. 
Rekishi Kentōkai Iinkai. (1995). (Ed.), Daitō Sensō no Sōkatsu, Tokyo, Tendensha, Sakada, Masahiro,Hō. (2014). no Banjin: Naikaku Hōseikyoku no Kyōji, Tokyo, Ōtsuki Shosen

Samuels, R, J. (2004). Politics, security policy, and Japan's cabinet legislation bureau: Who elected these guys, anyway? Japan Policy Research Institute Working Paper, no. 99. Retrieved from http://www.jpri. org/publications/workingpapers/wp99.html

Samuels, Richard J. (2007). Securing Japan: Tokyo's grand strategy and the future of East Asia, New York, Ithaca: Cornell University Press.

Shirai, Satoshi.(2014). Omoshirōte yagate kanshiki Abe-nokurashi. Sekai, no. 856, 107-16.

Sōsei Nippon.(2012). Sōsei Nippon: Sōsei Nippon undō hōshin. Retrieved from http:// www.sosei-nippon.jp/?page_id=2

Study team on the details leading to the drafting of the Kōno statement. (2014). Details of exchanges between Japan and the Republic of Korea (ROK) regarding the comfort women issue -from draft of the Kōno Statement to the Asian Women's Fund. Retrieved from https://www.mofa.go.jp/files/000042171

Suehiro, Akira. (2014). The road to economic re-entry: Japan's policy toward Southeast Asian development in the 1950s and 1960s. Social Science Japan Journal, 2(1), 85105.

Sunohara, Tsuyoshi. (2014). Nihonban NSC to wa Nani ka? Tokyo, Shinchō.

US Department of State. (2013, May 16). Daily press briefing. Retrieved from http://www. state.gov/r/pa/prs/dpb/2013/05/209511.htm\#JAPAN.

US Department of State, (2014, March 14). Daily press briefing. Retrieved from http:// www.state.gov/r/pa/prs/dpb/2014/03/223197.htm\#JAPAN

Suzuki, Yoshikatsu. (2014). Yachi shodai kokka anpochō ni kiku. Gaikō, 23, 68-77.

The American Presidency Project. (2007).The president's news conference with Prime Minister Shinzō Abe of Japan at Camp David, Maryland. Retrieved from https:// www.presidency.ucsb.edu/ws/?pid=25225

Tisdall, Simon. (2013). Shinzō Abe: Is Japan's PM a dangerous militarist or modernising reformer?. The Guardian. Retrieved from http:// www.theguardian.com/world/2013/ dec/16/shinzo-abe-japan-pm

Wakefield, Bryce and Martin, Craig. (2014).Reexamining myths about Japan's collective self-defense change: What critics (and the Japanese public) do understand about Japan's constitutional reinterpretation. The Asia Pacific Journal: Japan Focus, http:// www.japanfocus. org/events/view/227

Winkler, Christian G. (2011). The quest for Japan's new constitution: An analysis of the visions of constitutional reform proposals 1980-2009. London, Routledge.

Yachi, Shōtarō. (2010). Gaikō Senryaku to Kokorozashi, Tokyo, Sankei Shimbun Shuppan.

Yachi Shōtarō. (2013). Abe senryaku gaikō no kakushin: Kachikan, tetsugaku o kyōyū shi "Ajia" to gasshō suru. Gaikō, 18, 27-33.

Yanagizawa, Kōji, Handa, Shigeru., \& Yara, Tomohiro. (2013). Kaiken to Kokubō: Konmei Suru Anzen Hoshō no Yukue, Tokyo, Junpōsha.

Yoshihara, Toshi. (2014). Japanese hard power: Rising to the challenge". American Enterprise Institute for Public Policy Research.. Retrieved from http://www.aei.org/ files/2014/08/22/-japanese-hard-powerrising-to-the-challenge_152508260874 
1 Machiavelli's Children: Leaders and the their Legacies in Italy and Japan, New York, Ithaca: Cornell University Press, 2005, pp. 103-27; Kenneth B. Pyle, Japan rising: The resurgence of Japanese power and purpose, New York, Public Affairs, 2007, pp. 241-277.

2 Aida, Hiro. (2013). "(RIGHT TILT?) Does Shinzo Abe's Election Really Herald a More Militarist Japan?”. Kyodo News, 5 March 2013. http://www.japanpolicyforum.jp/archives/ politics/pt20130305170000.html, accessed on 10 November 2017.

3 NBR Analysis, Seattle, National Bureau of Asian Research, October 2006; David Pilling, Bending Adversity: Japan and the Art of Survival, London, Penguin Books, 2014, pp. 242-4; Christopher W. Hughes and Ellis S. Krauss, 'Japan's new security agenda', Survival, vol. 49, no. 2, 2007, pp. 157-176.

4 Matsumoto Kenichi, '(Right tilt?) Is "Japan's move to right" true? Second Abe administration faces test of realism', Discuss Japan: Japan Foreign Policy Forum, 5 March 2013, http://www. japanpolicyforum.jp/en/archives/politics/pt20130305180000.html; Aida Hiro, '(Right tilt?) Does Shinzo Abe's election really herald a more militarist Japan?', Discuss Japan: Japan Foreign Policy Forum, 5 March 2013, http://www.japanpolicyforum.jp/en/archives/politics/pt20130305170000. html.

5 Gerald L. Curtis, 'Japan's cautious hawks: why Tokyo is unlikely to pursue an aggressive foreign policy', Foreign Affairs, vol. 92, no. 2, March/April 2013, pp. 78-86; Brad Glosserman, 'Abe's Dilemmas',PacNet, no. 37, 30 May 2014, http://csis.org/publication/pacnet-37-abes-dilemmas; Kevin M. Doak, 'Shinzo Abe's Civic Nationalism', Japan Chair Platform, 15 May 2013,http:// csis.org/ publication/japan-chair-platform-shinzo-abes-civic-nationalism; Michael Penn, Japan and the War on Terror: Military Force and Political Pressure in the US-Japanese Alliance, London, I.B. Tauris, 2014, pp. 145, 251-252.

6 Richard, J., Samuels. (2007). Securing Japan: Tokyo's grand strategy and the future of East Asia. Ithaca, New York, Cornell University Press, 2007, pp. 30-31.

7 Kishi, Nobusuke. (1995). Kensei no Seijika. Tokyo, Iwanami Shinsho, 1995, pp. 91-92.

8 Akira Suehiro. (1999). The road to economic re-entry: Japan's policy toward Southeast Asian development in the 1950s and 1960s. Social Science Japan Journal, Vol. 2, no. 1, pp. 95-6; Hara, Kishi Nobusuke, 1999, pp. 189-190.

9 Richard Katz, Voodoo Abenomics: Japan's failed comeback plan,Foreign Affairs, Vol. 93, no. 3, July/August 2014, p. 141.

10 Abe talks of Japan never becoming a 'Tier-Two' nation, a terminology $\square$ borrowed, it seems, from a 2012 Center for Strategic and International Studies report, authored by two of Washington D.C.'s arch-'Japan handlers', Richard Armitage and Joseph Nye, that talked of the need for Japan to remain a 'Tier One' power. Shinzo Abe, Japan is back, 22 February 2013, CSIS, Washington D.C., https://www.mofa.go.jp/announce/pm/abe/ us_20130222en.html; Richard L. Armitage and Joseph S. Nye,The US-Japan alliance: Anchoring stability in Asia. Washington D.C., CSIS, 2012,https://csis. org/files/publication/120810_Armitage_USJapanAlliance_Web.pdf.

11 The quest for Japan's new constitution: An analysis of the visions of constitutional reform proposals 1980-2009, London, Routledge, 2011, pp. 50-8; Kobayashi Yoshinori, 'Shinzo Abe: sengo rejīmu no ritokusha o itsu made mo hōchi shite wa ikenai' ,Kibō no Kuni Nihon: Kyūjin no Seijika to Shinken Shōbu, Tokyo, Asuka Shinsha, 2010, p. 273. 
12 Yachi Shōtarō. (2013). Abe Senryaku Gaikō no Kakushin: Kachikan, Tetsugaku o Kyōyū Shi "Ajia" to Gasshō Suru'. Gaikō Vol. 18, March 2013, p. 28.

13 KOMPAS. (2017). "ASEAN Raih Jaminan China dalam Isu LCS. 15 November 2017.

14 Global Asia. Vol. 8, no. 2, Summer 2013, pp. 78-82. Abe secured victory in the 16 December 2012 election for the House of Representatives, with the LDP attaining an outright majority of 294 seats in the 480-seat chamber. This represented a gain of 176 seats following the LDP's own crushing defeat at the hands of the Democratic Party of Japan (DPJ) in the previous 2009 election. The LDP in coalition with the New Komeito Party and its 31 seats had a total majority of 325 seats. In the House of Councilors election on 21 July 2013, the LDP gained 31 seats for a total of 115 seats. Together with the 20 seats of the New Komeito, Abe's coalition administration gained a working majority in the 242-seat chamber, bringing to an end the so-called 'twisted' or divided National Diet that had hampered the DPJ in its legislative agenda. Abe called a snap election for the House of Representatives on 14 December 2014, in which the LDP lost three seats, and the New Komeito gained four seats, meaning that the coalition retained its majority.

15 Abe's photo opportunity in an ASDF T-4 trainer jet on 12 May 2013 inadvertently caused controversy in parts of East Asia when it was pointed out that the 731 number of the jet evoked memories of the notorious Unit 731 that researched biological and chemical warfare during the Second Sino-Japanese War of 1932-1945.

16 The Economist, 8 May 2013,https://www.economist.com/ news/leaders/21578044-shinzo-abehas-vision-prosperous-and-patrioticjapan-economics-looks-better.

17 Shinzo Abe, 'Japan is back', 22 February 2013, CSIS, Washington D.C., https:// www.mofa. go.jp/announce/pm/abe/us_20130222_en.html.

18 Andrew L. Oros, 'Does Abe's rightward shift threaten his legacy?', PacNet, no. 2, 7 January 2013,http://csis.org/publication/pacnet-2-does-abes-rightwardshift-threaten-his-legacy; Simon Tisdall, 'Shinzō Abe: Is Japan's PM a dangerous militarist or modernizing reformer?', The Guardian, 16 December 2013, http://www.theguardian.com/world/2013/dec/16/shinzo-abejapan-pm. 